\title{
Fattening of Young Beef Cattle on Hay Diets
}

\author{
Nina Tatarkina', Ekaterina Ponomareva ${ }^{1}$, and Firdus Safin ${ }^{2}$ \\ 1'Department of Technology for Production and Processing of Livestock Products, FSBEI HE GAU \\ Northern Trans-Urals, Tyumen, Russia \\ ${ }^{2}$ Zubr LLC, Golyshmanovsky District, Tyumen Region, Russia
}

\section{Abstract}

The article presents the results of studies on the use of hayfood rations from perennial legumes prepared in packaging film for feeding young cattle. The diets of feeding young cattle are balanced according to the main elements of nutrition, which made it possible to obtain average daily gains at the level of 10220--1244 grams. The nutritional value of the diets was almost the same in the groups and amounted to 9.33--9.39 energetic feed unit. It was found that animals treated with alfalfa and goat senator digested dry matter better by 7.83 and $3.4 \%$, crude protein by 5.41 and $1.87 \%$; crude fat by 19.89 and $4.67 \%$, crude fiber by 16.46 and $14.10 \%$ compared with calves receiving clover hay, respectively. Using silage diets from these crops improves energy

Corresponding Author:

Nina Tatarkina

ninatatarkinani@mail.ru

Received: 25 October 2019

Accepted: 15 November 2019

Published: 25 November 2019

Publishing services provided by

Knowledge E

(c) Nina Tatarkina et al. This

article is distributed under the

terms of the

Attribution License, which

permits unrestricted use and

redistribution provided that the

original author and source are credited.

Selection and Peer-review under the responsibility of the AgroSMART 2019 Conference Committee.

\section{G OPEN ACCESS} metabolism. The coefficient of productive use of metabolic energy by animals of the 3rd experimental group was $43.91 \%$, which is $5.15 \%$ more than in the 1st experimental group, by $8.60 \%$ from the 2nd experimental group. Animals of the 3 experimental groups were characterized by a higher slaughter yield, in comparison with other groups. The cost of feed per unit of increase in live weight of animals in group 2 was 9.19 energetic feed unit, which is 0.9 energetic feed unit and 1.73 energetic feed unit less than in 1 and 3 groups.

Keywords: haylage, young cattle, digestibility factors, live weight, meat productivity, slaughter yield.

\section{Introduction}

In recent years, for the organization of a balanced nutrition of cattle in general, the cultivation and fattening of young animals, haylage has been used. The technology of preparing haylage makes it possible to use green mass of legumes when mowing it in the budding phase, depending on zonal, soil and climatic conditions, during the season 2--3 times or more. According to researchers, this allows to increase the yield of green mass per hectare, to increase the nutritional value of the feed. In addition, haylage contains the most digestible nutrients, mineral elements and vitamins, is the best component of the winter diets of young cattle and provides good growth and development $[1,2]$. 
Since 2001, in the advanced farms of the Tyumen region, they switched to harvesting haylage into packaging film, which, in contrast to the traditional technology of preparing haylage, allowed to obtain better feed. Haylage prepared by this technology allows to reduce mechanical and biological losses during storage. According to some researchers, livestock productivity is growing by $20--25 \%$. due to the preservation of protein, sugar, vitamins in the haylage [3--7].

The type of feeding is fundamental in shaping the productivity of young cattle and the metabolism in his body [8]. The study of the effectiveness of the use of haylage from legumes prepared in a packaging film for fattening young breed of bull is relevant.

The aim was to study the effect of haylage from perennial legumes cooked in packaging film on the digestibility of nutrients, energy and mineral metabolism, on the fattening and meat productivity of young cattle breed obrak.

\section{Methods and Equipment}

To assess the productive value of rations represented by hay from legumes in Zubr LLC of the Golyshmanovsky District of the Tyumen Region during the stall period, scientific and economic and physiological experiments were carried out on bull bulls.

For this purpose, groups of animals were formed on the principle of pairs -- analogues, considering the origin, age, gender, level of productivity. The conditions of detention, the front of feeding and drinking, the microclimate parameters were the same in all groups. Accounting for the set feed was carried out daily, eatability -- once a decade, two adjacent days. The diets were normalized considering the chemical composition and nutritional value of feed based on the norms recommended by the RAAS [9].

Animals of the 1st experimental group were fed haylage prepared in a packing film from the Eastern goatskin, 2 experimental -- from the yellow melilot and 3 experimental -- blue-alfalfa. All animals were fed concentrates of their own production.

Against the background of scientific and economic experience, according to generally accepted methods, the digestibility of nutrients of diets and the state of energy, nitrogen and mineral metabolism were determined [10, 11].

The growth rate of young cattle was controlled by weighing when setting up for the experiment and monthly during the experiment. According to the results of weighing, the increase in live weight was determined. Assessment of meat productivity of animals was carried out according to generally accepted methods [12]. 


\section{Results}

Feeding experimental animals was carried out in accordance with the norms of feeding [9]. The daily consumption of haylage in the groups ranged from 12.2 to $14.7 \mathrm{~kg}$, concentrates $2.5 \mathrm{~kg}$. According to the structure of the diet, the share of haylage was 73 $\%$, the share of concentrated feed was $27 \%$, therefore, hay-concentrate type of feeding was used.

The digestibility of nutrients in diets is influenced by many factors: the quality of the feed, its intake in the daily intake, the usefulness of the diet, animal welfare conditions and the general level of feeding $[13,14]$. The digestibility ratios of nutrients are given in table 1.

TABLE 1: Coefficients of digestibility of nutrients of diets by animals during the period of physiological experience, \% $(\overline{\%} \pm S \bar{x})$.

\begin{tabular}{|c|c|c|c|}
\hline \multirow[t]{2}{*}{ Indicator } & \multicolumn{3}{|c|}{ Group } \\
\hline & 1 experienced & 2experienced & 3experienced \\
\hline Dry matter & $70.4 \pm 0.9$ & $66.9 \pm 1.7$ & $74,8 \pm 0.4^{* *}$ \\
\hline Organic matter & $72.0 \pm 0.8$ & $69.2 \pm 1.7$ & $76.1 \pm 0.4^{* *}$ \\
\hline Crude protein & $66.6 \pm 1.1$ & $64.8 \pm 1.6$ & $70.2 \pm 0.2^{* *}$ \\
\hline Crude fat & $69.4 \pm 3.1$ & $64.8 \pm 2.1$ & $84.6 \pm 0.9^{* * *}$ \\
\hline Crude fiber & $64.7 \pm 1.2^{* *}$ & $50.6 \pm 1.2$ & $67.1 \pm 0,6^{* * *}$ \\
\hline $\begin{array}{l}\text { nitrogen-free extractive } \\
\text { substances }\end{array}$ & $69.6 \pm 0.9$ & $69.2 \pm 1.7$ & $75.1 \pm 1.2$ \\
\hline
\end{tabular}

Note: hereinafter * -- $\pi \mathrm{a}>0.95 ;^{* *}--\pi \mathrm{a}>0.99 ;^{* * *}--\pi \mathrm{a}>0.999$

The data in the table show that the digestibility factor of dry matter in the diets of animals of the 3rd experimental group receiving hay alfalfa was $74.8 \%$, which is $4.4 \%$ more than in the group receiving haylage from goatskin (experimental) (2 experimental) -- by $7.8 \%$ (P> 0.99).

The digestibility of protein in the group receiving hayfields from alfalfa is $3.5 \%$ higher than in the group that consumed hayfields from goatberry and by $5.4 \%(P>0.99)$, receiving hayfields from clover. The increase in the digestibility of raw feed protein is due to the activity of cicatricial microflora, as well as proteolytic enzymes, due to which the processes of the breakdown of feed protein to polypeptides, peptides, amino acids and ammonia proceeded more actively while synthesizing a bacterial protein of high biological value.

A significant difference in the digestibility of crude fat between 3 and 2 experimental groups was established $(P>0.99)$. There is a significant difference between the 
digestibility of crude fiber in the 3rd and 2nd experimental groups -- $16.5 \%$ (P> 0.99), between the 1st and 2nd experimental groups --14.1\% ( $P>0.99)$.

Food is an energy source for animals. The potential energy of the feed released from the body during the breakdown of organic substances is used to carry out various physiological functions of the animal and its vital functions [8] (table 2).

TABLE 2: Energy balance of rations (on average per head per day), MJ ( $\overline{\%} \pm S \bar{x})$.

\begin{tabular}{|c|c|c|c|}
\hline \multirow[t]{2}{*}{ Indicator } & \multicolumn{3}{|c|}{ Group } \\
\hline & 1 experienced & 2experienced & 3experienced \\
\hline Gross Diet Energy & $159.1 \pm 1.7$ & $163.2 \pm 0.6$ & $152.8 \pm 0.5$ \\
\hline $\begin{array}{l}\text { Digestible energy \% of } \\
\text { gross energy }\end{array}$ & $66.7 \pm 0.9$ & $63.0 \pm 1.8$ & $71.1 \pm 0.4^{* *}$ \\
\hline Exchange energy & $85.5 \pm 1.5$ & $84.0 \pm 2.5$ & $88.1 \pm 0.4$ \\
\hline $\begin{array}{l}\text { Metabolic energy in \% of } \\
\text { digestible }\end{array}$ & 80.59 & 81.69 & 81.07 \\
\hline Product Energy & $11.8 \pm 0.2$ & $11.6 \pm 0.4$ & $12.5 \pm 0.1$ \\
\hline Heat production energy & $73.7 \pm 1.3$ & $72.4 \pm 2.2$ & $75.6 \pm 0.4$ \\
\hline $\begin{array}{l}\text { Energy products in \% of the } \\
\text { exchange }\end{array}$ & 13.81 & 13.85 & 14.13 \\
\hline Growth energy & $14.3 \pm 0,2^{*}$ & $13.1 \pm 0.9$ & $15.7 \pm 1.5$ \\
\hline $\begin{array}{l}\text { The coefficient of } \\
\text { productive use of OE, \% }\end{array}$ & 38.76 & 35.31 & 43.91 \\
\hline
\end{tabular}

A study of the exchange and nature of energy use in the body of experimental gobies showed that animals of the 1st experimental group with the adopted food received a gross energy less by $4.1 \mathrm{MJ}$ and by $10,4 \mathrm{MJ}$ in the 3 experimental compared to the 2 experimental group.

The energy digestibility coefficient in gobies of the 3 experimental group was $71.1 \%$, which is $8.1 \%$ more than in the 2 experimental and $4.4 \%$, compared with 1 experimental. In the diet of animals of the 3rd group, 88.1 MJ accounted for exchange energy, for peers of the 1st experimental group -- $2.6 \%$, in the 2 nd experimental group -- $4.1 \%$ less (the difference is not significant).

The main factors that determine the growth of farm animals should be considered the breed and the balance of rations for the main nutrients $[15,16]$. Live weight and average daily gain are the most important indicators characterizing the growth, development and meat productivity of the animal (table 3 ). 
TABLE 3: Change in live weight of gobies, $(\overline{\%} \pm S \bar{x})$.

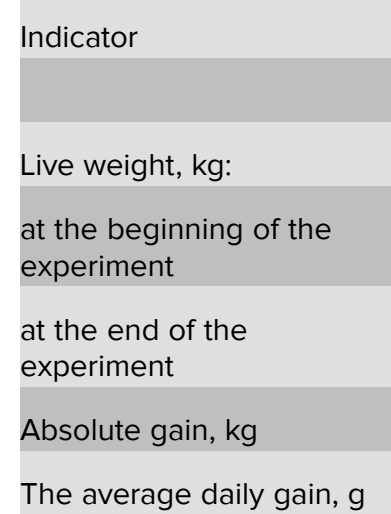

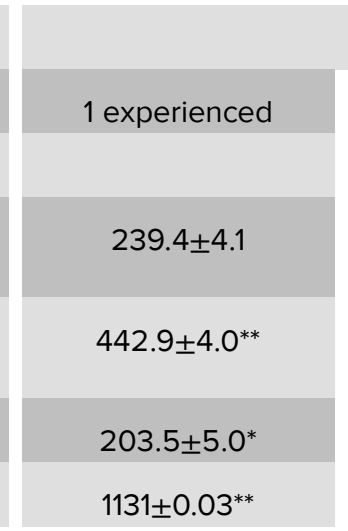

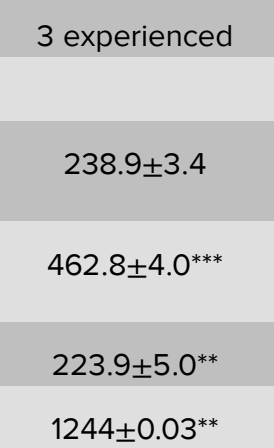

The live weight of bulls during the main period of the experiment increased in 1 experimental -- by $203.5 \mathrm{~kg}$, in 2 experimental -- by $183.9 \mathrm{~kg}$ and in 3 experimental -by $223.9 \mathrm{~kg}$.

In conditions of intensive rearing of bull-calves on hayfood rations from alfalfa and goat's, their meat productivity significantly increased, the indicators of which are given in table 4.

In animals of the 3 experimental group, the slaughter yield was $60.2 \%$, which is $3.3 \%$ more than in animals of the 2 nd group, by 1.9 , compared with 1 experimental. The meat index met the requirements for beef cattle in 1 and 3 experimental groups. In animals of the 2 nd experimental group, this indicator is below the standard by $0.6 \mathrm{~kg}$.

The protein content in the longest muscle of the back of the studied groups was at the level of 22.8--23.2\%. The content of intramuscular fat in the longest muscle of gobies 3 of the experimental group was $0.7 \%$, which is 0.3 and $0.2 \%$ more in comparison with 1 and 2 experimental groups, respectively. Moreover, an increase in the content of intramuscular fat in the longest muscle of the back of the 3rd experimental group was accompanied by a decrease in the amount of protein (22.8\%). The energy value of $1 \mathrm{~kg}$ of the longest muscle of the back of the gobies of the experimental groups was almost the same and was in the range of 4.15--4.19 MJ.

A study of the biological value of meat showed that the content of tryptophan in the longest muscle of the back in animals of the experimental groups was at the level of 2.8--3.0 g. In the context of groups, the dynamics of a decrease in the content of tryptophan with increasing live weight of the animals was noted. Having a large live weight, animals of group 3 in terms of tryptophan content were $8.6 \%$ inferior to peers from group 1 and $1.1 \%$ in experimental group 2 . The content of oxyproline in the longest muscle of the back in animals of the 1st experimental group was $0.6 \mathrm{~g}, 2$ and 3 of the experimental group -- $0.5 \mathrm{~g}$ per $1 \mathrm{~kg}$. The total amino acid content in the longest muscle 
of the back in animals of group 3 was $169.1 \mathrm{~g}$, which is $1.0 \%$ more than in peers 1 and 1.4 in 2 of the experimental group.

TABLE 4: The meat productivity of gobies, $(\overline{\%} \pm S \bar{x})$.

\begin{tabular}{|c|c|c|c|}
\hline \multirow[t]{2}{*}{ Indicator } & \multicolumn{3}{|c|}{ Group } \\
\hline & 1 experienced & 2 experienced & 3 experienced \\
\hline \multicolumn{4}{|l|}{ Weight, kg } \\
\hline pre-slaughter & $456.7 \pm 1.7^{* *}$ & $432.3 \pm 2.7$ & $490.0 \pm 7.6^{* *}$ \\
\hline Carcass weight & $266.4 \pm 2.6^{* *}$ & $246.3 \pm 1.5$ & $295.0 \pm 6.1^{* * *}$ \\
\hline pulp & $220.5 \pm 2.2^{* *}$ & $200.9 \pm 1.2$ & $244.3 \pm 5.6^{* * *}$ \\
\hline Internal fat & $4.6 \pm 0.1^{* *}$ & $4.5 \pm 0.1^{*}$ & $5.0 \pm 0.1^{* * *}$ \\
\hline bones & $45.8 \pm 0.5$ & $45.4 \pm 0.4$ & $50.7 \pm 0.8^{* * *}$ \\
\hline Slaughter yield, \% & $58.3 \pm 0.6^{*}$ & $56.9 \pm 0.2$ & $60.2 \pm 0.5^{* *}$ \\
\hline The yield of pulp, \% & 82.8 & 81.6 & 82.8 \\
\hline Meat ratio & $4.8 \pm 0.04^{* *}$ & $4.4 \pm 0.03$ & $4.8 \pm 0.07^{*}$ \\
\hline
\end{tabular}

The efficiency of fattening young cattle on hay diets prepared using hay technology in packaging from perennial leguminous crops showed that the feed consumption in the energetic feed unit in all groups was almost the same for the experimental period. In the 3 experimental group, it amounted to 1670.4 energetic feed unit, which is $1.2 \%$ less than in the 2 experimental, $1.0 \%$-- from 1 experimental.

\section{Discussion}

The total nutritional value of the diets was almost the same in the experimental groups and amounted to 9.33--9.39 energetic feed unit. The concentration of exchange energy in the dry matter of the diet in gobies of the experimental groups was in the range of 11.6--12.0 MJ. The content of crude protein from dry matter in the analyzed diets was from 14.2 to $15.3 \%$, with a norm of $13.8-15.0 \%$ [11]. In the studied rations, a rather high content of crude fiber to the dry matter of the diet in 1 experimental -- 34.5, in 2 experimental -- 29, 9 and in 3 experimental -- $33.2 \%$. The most favorable for animals is the content of $20--23 \%$, but not more than $25 \%$ of crude fiber from dry matter [11].

The balance of animal diets has a significant effect on the digestibility of nutrients, and the best results are achieved by feeding goose with alfalfa and goat goats.

The percentage of production energy use from metabolic energy in the diets of animals of the 3 experimental group is higher and equal to $14.13 \%$, which is $0.28 \%$ more than the energy used by the animals of the 2 experimental group, by $0.32 \%$, 
compared with 1 experimental group. Gobies of the 3 experimental group had a high energy gain in live weight and spent more metabolic energy to maintain life than animals of other groups. Also, the diet of this group was characterized by a high coefficient of productive use of metabolic energy. KPI OE amounted to $43.91 \%$ in the 3 experimental group, which is $5.15 \%$ more than in the 1 experimental group, by $8.60 \%$ with the 2 experimental group.

The results obtained indicate a higher growth energy of animals of the 3rd experimental group. In this group, the live weight of gobies increased by $9.5 \%$ ( $P>0.99$ ), in one experimental group -- by $4.8(\mathrm{P}>0.95)$ in comparison with 2 experimental. The average daily gain in live weight of gobies in 1 experimental $1131 \mathrm{~g}$, which is $10.7 \%$ more $(P>0.99)$, in 3 experimental, $1244 \mathrm{~g}$, or $21.7 \%$ more $(P>0.99)$ than in 2 experienced.

Animals of the 3 experimental groups were characterized by a higher slaughter yield, in comparison with other groups. The highest biological value of the longest muscle of the back was observed in gobies of the 1st experimental group, which exceeded peers of the 2 nd and 3rd experimental groups by BKP by 2.3 and $3.3 \%$, respectively.

The cost of feed per $1 \mathrm{~kg}$ of live weight gain was higher in the 2 nd experimental group and amounted to 9.19 energetic feed unit, in the 1st experimental this indicator is lower by 0.9 energetic feed unit and in the 3rd experimental -- by 1.73 energetic feed unit.

\section{Conclusion}

Consequently, the diets of feeding young cattle are balanced according to the main elements of nutrition, which allowed to obtain average daily gains at the level of 10220-12440 grams. When feeding silage in a package of alfalfa, a synehybrid and eastern goatberry increases the digestibility of nutrients, improves energy metabolism, which leads to higher fattening and meat productivity and lower feed costs per unit of increase in live weight of animals.

\section{Funding}

The studies are part of scientific research aimed at increasing the usefulness of feeding highly productive animals (state registration number 0120.0503976 ). 


\section{Conflict of Interest}

This article does not affect anyone's interests.

\section{References}

[1] Levakhin, Yu. (2004). The influence of harvesting technology on the nutritional value of sweet clover feed. Dairy and beef cattle breeding, no. 1, pp. 10--11.

[2] Semykin, V.A., Bykov, V.S., Sinyavskaya, L.V. et al. (2008). Improving the technology of harvesting haylage. Collection of the international practical conference "Actual problems of the efficiency of the agro-industrial complex, Kursk State Agricultural Academy named after Professor I.I. Ivanov". Kursk, pp. 283--285.

[3] Bondarev, V. (2003). We stock feed using new technologies. Livestock of Russia, no. 1. pp. 36--37.

[4] Kurdoglyan, A.A. (2002). The technology of harvesting haylage in film packaging using the Salyut machine complex. International Scientific and Practical Conference "Actual problems of the development of livestock and feed production: theory and practice". (16--17 May 2002). Kurgan, pp. 56--57.

[5] Korobov, A.P., Moskalenko, S.P., Kuznetsov, M.Yu. (2005). Comparative effectiveness of feeding silage cows with different harvesting technologies. Zootechnics, no. 2 , pp. 12--13.

[6] Moskalenko, S.P. Korobov, A.P. (2005). Packed haylage in diets of repair heifers. Zootechnics, no. 10, pp. 7--8.

[7] Tatarkina, N.I. (2008). The effect of feeding different types of haylage on the meat productivity of young cattle. Siberian Bulletin of Agricultural Science, no. 4, pp. 73-77.

[8] Makartsev, N.G. (2012). Feeding farm animals. Textbook for high schools, 3rd ed. reprinted and supplemented. Kaluga: The Noosphere, $640 \mathrm{p}$.

[9] Kalashnikov, A.P., Fisinin, V.I., Kleimenov, N.I. et al. (2003). Norms and diets for feeding farm animals. Reference manual, 3rd ed. revised and expanded. Moscow, 456 p.

[10] Grigoriev, N.G., Melnichenko, A.I., Embulatov, A.I. (1984). Guidelines for determining the energy nutritional value of feed for ruminants. Moscow: VASKHNIL, pp. 15--34.

[11] Nadalyak, E.A. Agafonov, V.I. et al. (1986). Study of metabolism and energy nutrition in farm animals. Method icalinstructions. Borovsk, pp. 48--56.

[12] Assessment of meat productivity of cattle (2001). Recommendations: Sib. branch of RAAS, vol. 2, ext. revisions. SibNIPTIZH, SibNIIMS. Novosibirsk, 155 p. 
[13] Levakhin, Yu.I., Taspaeva, E.Yu., Zankina, A.Yu. (2018). The effect of various fodders from a legume-cereal mixture on the digestibility of nutrients in the diet and the energy exchange in the body of fattened gobies. Materials of the international scientific -- practical conference "Nanotechnology in agriculture: prospects and risks". pp. 97--101.

[14] Tatarkina, N.I. (2009). Theoretical basis for increasing the efficiency of feeding beef and dairy cattle in the conditions of the Northern Trans-Urals. PhD dissertation thesis. Troitsk, $40 \mathrm{p}$.

[15] Bakharev, A.A., Sheveleva, O.M., Fomintsev, K.A. et al. (2018). Biotechnologigal characteristics of meat cattle breeds in the Tyumen region. Journal of Pharmaceutical Sciences and Research, vol. 10, no. 9, 2383 p.

[16] Sheveleva, O.M. Bakharev, A.A., Lysenko, L.A., Krinitsina T.P. (2017). Comparative assessment of the meat productivity of cattle of the breed of different species of genetically -- ecological generations in the conditions of the Northern Trans-Urals. Agro Eco Info, no. 4(30), pp. 27. Retrieved from: http://agroecoinfo.narod.ru/journal/ 